\title{
Effect of Synthesis Method on the Catalytic Performance of Ca-Mg-Al Mixed Metal Oxide Nanocatalyst for Biodiesel Production from Waste Cooking Oil
}

\author{
Mansoor Anbia*, Sotoudeh Sedaghat, Samira Salehi, Sholeh Masoomi \\ Research Laboratory of Nanoporous Materials, Faculty of Chemistry, Iran University of Science and Technology, Farjam Street, \\ Narmak, P.O. Box 16846-13114, Tehran, Iran \\ E-mail: anbia@iust.ac.ir
}

Received: 25 December 2020; Revised: 21 April 2021; Accepted: 27 April 2021

\begin{abstract}
The synthesized nanomaterials by two different methods were used as a catalyst in the transesterification of waste cooking oil to produce biodiesel. For both environmental and economic reasons, it is beneficial to produce biodiesel from waste cooking oils. It is desirable to help solve waste oil disposal by utilizing its oils as an inexpensive starting material in biodiesel synthesis. The structure, morphology, and surface properties of resulting nanocatalysts were characterized by X-ray Fluorescence Spectroscopy (XRF), Scanning Electron Microscopy (SEM), X-Ray Diffraction (XRD), Fourier Transform Infrared Spectroscopy (FT-IR), Energy Dispersive X-ray Spectroscopy (EDX) and $\mathrm{N}_{2}$ adsorption-desorption isotherms. The synthesized nanocatalysts' efficiency in the production of biodiesel was studied by Gas Chromatography (GC) as well as leaching amounts of surface active components of each catalyst investigated by the EDX technique. The reactions were performed at $65^{\circ} \mathrm{C}$ using a 9:1 methanol to oil ratio for $3 \mathrm{~h}$. The results indicate that the impregnated mixed metal oxide catalyst ( $\mathrm{Ca}-\mathrm{MgAl})$ shows a higher surface area and better mechanical strength than the totally co-precipitated mixed metal oxide catalyst $(\mathrm{CaMgAl}(\mathrm{O}))$. Although both of the fully co-precipitated and impregnated catalysts represented about $90 \%$ of fatty acid methyl esters (FAME) yield the leaching of active calcium component was significantly reduced from $45.8 \%$ in precipitated $\mathrm{CaMgAl}(\mathrm{O})$ to $8 \%$ for the impregnated $\mathrm{Ca}-\mathrm{MgAl}$ catalyst. This improved structure represents the advantage of the impregnation technique to co-precipitation procedure for fabrication of robust nanostructures.
\end{abstract}

Keywords: mixed oxide, co-precipitation, impregnation, biodiesel production, nanocatalyst

\section{Introduction}

It has become essential to find clean alternative and renewable energy resources because of the limited conventional fossil fuels, harmful environmental impacts, and severe climate changes [1-3]. Biodiesel is termed as a viable substitute to petroleum-based diesel that can reduce or solve the effects of air pollution due to various desired properties including its renewability and better combustion characteristics [4].

The costs of raw materials for biodiesel production accounts for a large percentage of the direct biodiesel

Copyright (C2021 Mansoor Anbia, et al.

DOI: https://doi.org/10.37256/est.212021759

This is an open-access article distributed under a CC BY license

(Creative Commons Attribution 4.0 International License)

https://creativecommons.org/licenses/by/4.0/ 
production costs required. Thus, one way of reducing the biodiesel production costs is to use the less expensive raw material containing fatty acids such as animal fats, non-edible oils, waste cooking oils, and byproducts of the refining vegetable oils [5-7]. The use of waste cooking oil for biodiesel production can also help in solving the problem of waste oil disposal [8-9]. The cost of waste oil mainly arises from the costs in the collection, transportation, and pretreatment.

Biodiesel is a combination of fatty acid ethyl esters (FAEEs) or fatty acid methyl esters (FAMEs) obtained by the transesterification of triglycerides derived from plant oils or animal fats together with alcohols, in the presence of appropriate catalysts [10-12]. The transesterification reaction is carried out by employing acidic/basic-heterogeneous or homogeneous catalysts [13-15]. Heterogeneous catalysts are easily separated from the system at the end of the process and can be reused. Besides, they are environmentally friendly, have a long lifetime and can provide high activity and selectivity [16-19]. In the industrial world, the catalysts used must be pure, stable to heat, have a long lifetime, can be regenerated, are resistant to poisoning, are simple in the way they are made, and are easy to obtain and inexpensive. Very recently, several investigations were devoted to developing numerous heterogeneous catalysts for the transesterification reaction of oils for biodiesel production [20-22]. Among these heterogeneous catalysts, metal oxides were reported to exhibit interesting catalytic performances [23-25].

Calcium oxide $(\mathrm{CaO})$ is an efficient and economical catalyst that was utilized to produce biodiesel. Although $\mathrm{CaO}$ is a high-performance catalyst, this type of catalyst requires high leaching during the reaction [26]. It should also be noted that the existence of $\mathrm{CaO}$ in the reaction mixture leads to separation problems of catalyst from biodiesel products [27-28]. In recent years, researchers have tried to solve the intrinsic leaching problem, and also improve the activity of the catalysts. To attain these goals, mixed metal oxide catalysts have been prepared and investigated. Among available mixed metal oxide catalysts, Ca-based mixed oxide is regarded as one of the most favourable catalysts owing to its low cost and high basicity [29]. Peterson and Scarrah, [30] reported a $\mathrm{CaO}$. $\mathrm{MgO}$ mixed-oxide is a heterogeneous catalyst used to obtain FAMEs from low erucic rapeseed oil with improved production yield. In another study on mixed metal oxides, catalysts based on $\mathrm{CaO}-\mathrm{MgAl}$ oxides were synthesized by calcium dinitrate tetrahydrate impregnation onto $\mathrm{MgAl}$ hydrotalcite. The results confirmed that the $\mathrm{Ca}$ loading onto MgAl mixed oxide leads to enhance the activity of catalyst with low leaching [31].

Magnesium oxide $(\mathrm{MgO})$ catalysts have also been used as a basic catalyst for transesterification reaction. These catalysts possess weak basic sites, but the low amount of loading of $\mathrm{Al}^{3+}$ cations onto $\mathrm{MgO}$ constructed new support of Lewis acid-base pair sites [32]. Liu et al. [33] employed MgAl hydrotalcite as a heterogeneous basic catalyst for the conversion of poultry lipids to biodiesel. Experimental data showed that calcination at $500^{\circ} \mathrm{C}$ can increase the catalytic activity. An eco-friendly process for the metanalysis of vegetable oils to MEs through calcined MgAl hydrotalcite reported by Xie et al. [34] The catalyst with $\mathrm{MgAl}$ ratio of 3.0 achieved by the calcination at $500^{\circ} \mathrm{C}$ revealed the high basicity and catalytic activity.

In our previous study, we have reported developing a Zn-based transesterification catalyst [35]. While in this investigation we have used calcium as an active catalytic component. Although both works are following the same concepts for studying the effect of fabrication technique on the leaching of the active components, in this study a highly efficient Ca-based catalyst was successfully obtained compared to the Zn-based catalyst. Besides, the aim of this work is to solve the leaching problem of Ca-based MgAl mixed oxide without decreasing its catalytic activity. To achieve this goal, the nanostructures of this mixed oxide were synthesized through two simple and approximately low-cost methods, followed by the comparison of their catalytic activity, and component leaching. The textural/structural and morphological features of prepared catalysts were studied by various characterization techniques such as FT-IR, XRF, XRD, EDX, SEM and $\mathrm{N}_{2}$ adsorption-desorption isotherms. The reaction was performed under similar conditions for both catalysts and waste cooking oil was used as feedstock.

\section{Experimental procedure}

\subsection{Synthesis of nanoporous catalysts}

Fabrication of co-precipitated $\mathrm{CaMgAl}(\mathrm{O})$ was performed using $8.54 \mathrm{~g}$ of $\mathrm{Mg}\left(\mathrm{NO}_{3}\right)_{2} \cdot 6 \mathrm{H}_{2} \mathrm{O}, 8.54 \mathrm{~g}$ of $\mathrm{Ca}\left(\mathrm{NO}_{3}\right)_{2} \cdot 4 \mathrm{H}_{2} \mathrm{O}$, and $12.50 \mathrm{~g}$ of $\mathrm{Al}\left(\mathrm{NO}_{3}\right)_{3} \cdot 9 \mathrm{H}_{2} \mathrm{O}$ (including 0.0333 mole of each salt) in $100 \mathrm{~mL}$ of deionized water. Another solution of $7.95 \mathrm{~g}$ of $\mathrm{Na}_{2} \mathrm{CO}_{3}$ and $4 \mathrm{~g}$ of $\mathrm{NaOH}$ was prepared in $100 \mathrm{~mL}$ of deionized water and was added as 
precipitator to the first solution under vigorous stirring. The $\mathrm{pH}$ was adjusted on 8-10 during the process and the mixture was aged at $50-60^{\circ} \mathrm{C}$ for $24 \mathrm{~h}$. The final product was filtered and dried in the oven of $100^{\circ} \mathrm{C}$ for $12 \mathrm{~h}$ and calcinated at $500^{\circ} \mathrm{C}$ for $4 \mathrm{~h}$.

For fabrication of impregnated $\mathrm{Ca}-\mathrm{MgAl}$, first, the catalyst substrate of $\mathrm{MgAl}$ was made using $23.07 \mathrm{~g}$ of $\mathrm{Mg}\left(\mathrm{NO}_{3}\right)_{2} \cdot 6 \mathrm{H}_{2} \mathrm{O}, 8.33 \mathrm{~g} \mathrm{Al}\left(\mathrm{NO}_{3}\right)_{3} \cdot 4 \mathrm{H}_{2} \mathrm{O}$, was dissolved in $180 \mathrm{~mL}$ of deionized water $(\mathrm{Mg}$ : $\mathrm{Al}$ molar ratio of 1:1). Then the precipitating solution of $12.89 \mathrm{~g} \mathrm{Na}_{2} \mathrm{CO}_{3}$ and $16.26 \mathrm{~g}$ of $\mathrm{NaOH}$ in $203.25 \mathrm{~mL}$ deionized water was added to the first solution. The solution was aged at $60-65^{\circ} \mathrm{C}$ for $18 \mathrm{~h}$, then was filtered and washed till neutral $\mathrm{pH}$. The precipitate was dried for $12 \mathrm{~h}$ at $80^{\circ} \mathrm{C}$, calcinated at $600{ }^{\circ} \mathrm{C}$ for $30 \mathrm{~min}$, and was labelled as $\mathrm{MgAl}(\mathrm{O})$. For impregnation of $\mathrm{Ca}$ to the $\mathrm{MgAl}(\mathrm{O}), 2.10 \mathrm{~g}$ of $\mathrm{MgAl}(\mathrm{O})$ and $0.84 \mathrm{~g}$ of $\mathrm{Ca}\left(\mathrm{NO}_{3}\right)_{2} \cdot 4 \mathrm{H}_{2} \mathrm{O}$ was dissolved in $50 \mathrm{~mL}$ of deionized water and transferred to the rotary evaporator. The impregnation process was performed at $400 \mathrm{mbar}$, and temperature of $75^{\circ} \mathrm{C}$ under $400 \mathrm{rpm}$ for $150 \mathrm{~min}$. The final product was dried at $90^{\circ} \mathrm{C}$ for $12 \mathrm{~h}$ and calcinated at $600^{\circ} \mathrm{C}$ for $30 \mathrm{~min}$.

\subsection{Transesterification reaction of waste oil}

These as-prepared catalysts were applied for the transesterification of waste cooking oil as feedstock with methanol $(99.5 \%$, Merck) to produce biodiesel fuel. Waste cooking oil provided from the "Nane Tehran confectionary" was pretreated before transesterification reactions. For pretreatment, the waste cooking oil was filtered to remove suspended impurities. After filtering, the resulting oil was placed in a furnace at $60^{\circ} \mathrm{C}$ for $30 \mathrm{~min}$. The resulting product was used as the feedstock for the transesterification process. The reaction was conducted by mixing methanol (3.27 g), waste oil (10 $\mathrm{g})$, as well as catalyst ( $0.3 \mathrm{~g}$ of one of the prepared catalysts). The resulting mixtures were allowed to react under stirring for $90 \mathrm{~min}$ in a refluxing system at $85^{\circ} \mathrm{C}$.

For separation of the produced biodiesel, the reaction mixture was centrifuged at $4000 \mathrm{rpm}$ for 15 min to remove the catalyst from the mixture. Then the mixture was transferred to a separatory funnel to separate glycerol and other impurities (Figure 1 shows this two-step separation process). The methanol residues were removed by heating the mixture in an oven of $60^{\circ} \mathrm{C}$ for $1 \mathrm{~h}$. The product was analyzed using GC.
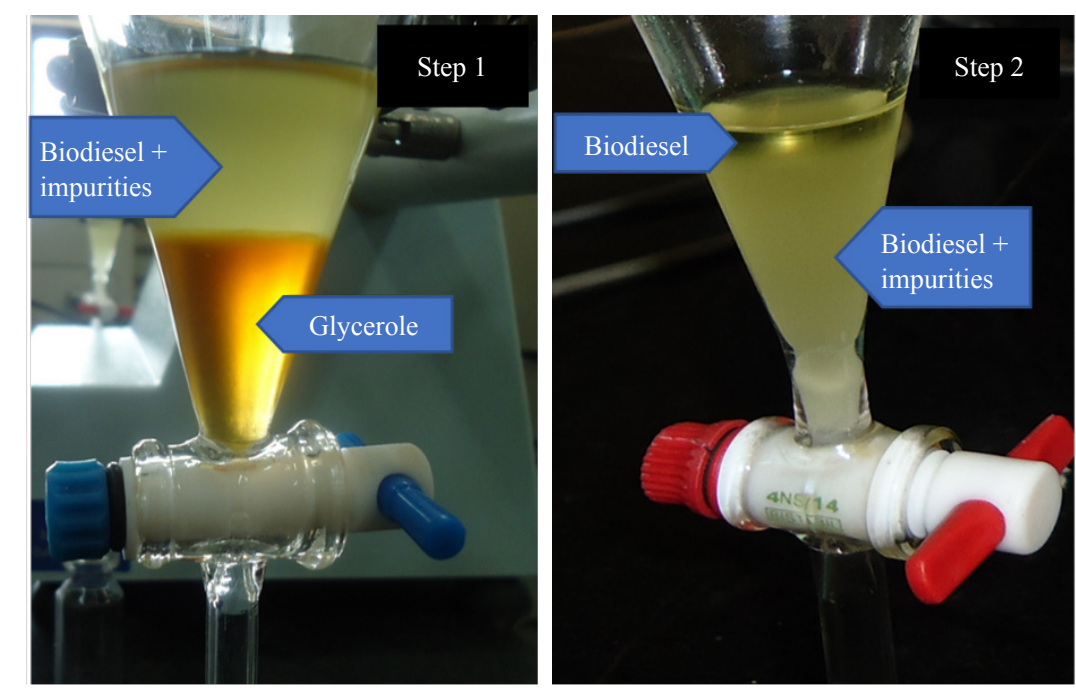

Figure 1. Separation of biodiesel from the impurities and glycerol

\subsection{Measurement and characterization}

The basic strength of the as-prepared catalysts was assessed by the method that is previously reported by Fraile et al. [36]. To examine the structures and crystallite size of the as-prepared mixed metal oxides, XRD measurements were done (X'pert diffractometer, Philips). The surface morphology and elemental composition of mixed metal oxides were 
simultaneously checked by SEM equipped with an EDX detector (XL30ESEM-TMP, Philips). XRF analysis was used for further and more accurate identification of samples and elemental composition (PW1410, Philips). To determine the presence of functional groups of $\mathrm{Ca}-\mathrm{MgAl}$ and $\mathrm{CaMgAl}(\mathrm{O})$, FTIR spectra were applied (AVATAR instrument). The average pore size $\left(\mathrm{A}_{\mathrm{P}}\right)$ and specific surface area $\left(\mathrm{S}_{\mathrm{BET}}\right)$ of the $\mathrm{Ca}-\mathrm{MgAl}$ and $\mathrm{CaMgAl}(\mathrm{O})$ were estimated at $77 \mathrm{~K}$ via Micromeritics ASAP 2010 analyzer. Pore size distribution (PSD) was calculated from the adsorption branch of the isotherm through the Barrett, Johner and Halenda $(\mathrm{BJH})$ method. The $\mathrm{S}_{\mathrm{BET}}$ was acquired from the linear part of the Brunaure, Emmet and Teller (BET) equation.

The Gas chromatography-flame ionization detector (GC-FID, Perkin-Elmer, Clarus 580) was used for the determination of the FEME content of transesterification products. A CP9080 capillary column $(30 \mathrm{~m} \times 0.32 \mathrm{~mm} \times 1.0$ $\mu \mathrm{m})$ was applied for the separation. The gas $(99.9999 \%)$ was employed as carrier gas at a flow rate of $2.0 \mathrm{~mL} / \mathrm{min}$. The oven temperature was initially held at $60^{\circ} \mathrm{C}$ for $2 \mathrm{~min}$, increased to $230^{\circ} \mathrm{C}$ at $5^{\circ} \mathrm{C} / \mathrm{min}$ and then held for $10 \mathrm{~min}$. The injector and detector temperatures were held at $250^{\circ} \mathrm{C}$.

\section{Results and discussion}

Basicity of the co-precipitated $\mathrm{CaMgAl}(\mathrm{O})$ and impregnated $\mathrm{Ca}-\mathrm{MgAl}$ catalysts are given in Table 1. The basic strength of the co-precipitated product is higher than that of the impregnated one, and the catalytic activity of $\mathrm{CaMgAl}(\mathrm{O})$ is better than that of the Ca-MgAl. The higher basicity of co-precipitation product is due to synthesis conditions like more carbonate salt consumption during the synthesis process and to perform synthesis at alkaline $\mathrm{pH}$.

Table 1. Initial Ca content, basicity, $A_{P}$ and $S_{B E T}$ of synthesized catalysts

\begin{tabular}{ccccc}
\hline Catalyst type & Initial Ca content $(\mathrm{wt} \%)$ & Basicity $(\mathrm{mmol} / \mathrm{g})$ & $\mathrm{A}_{\mathrm{P}}(\mathrm{nm})$ & $\mathrm{S}_{\mathrm{BET}}\left(\mathrm{m}^{2} / \mathrm{g}\right)$ \\
\hline $\mathrm{CaMgAl}(\mathrm{O})$ & 71.74 & 0.91 & 22.25 & 20.239 \\
$\mathrm{Ca}-\mathrm{MgAl}$ & 33.82 & 0.70 & 20.04 & 91.19 \\
\hline
\end{tabular}

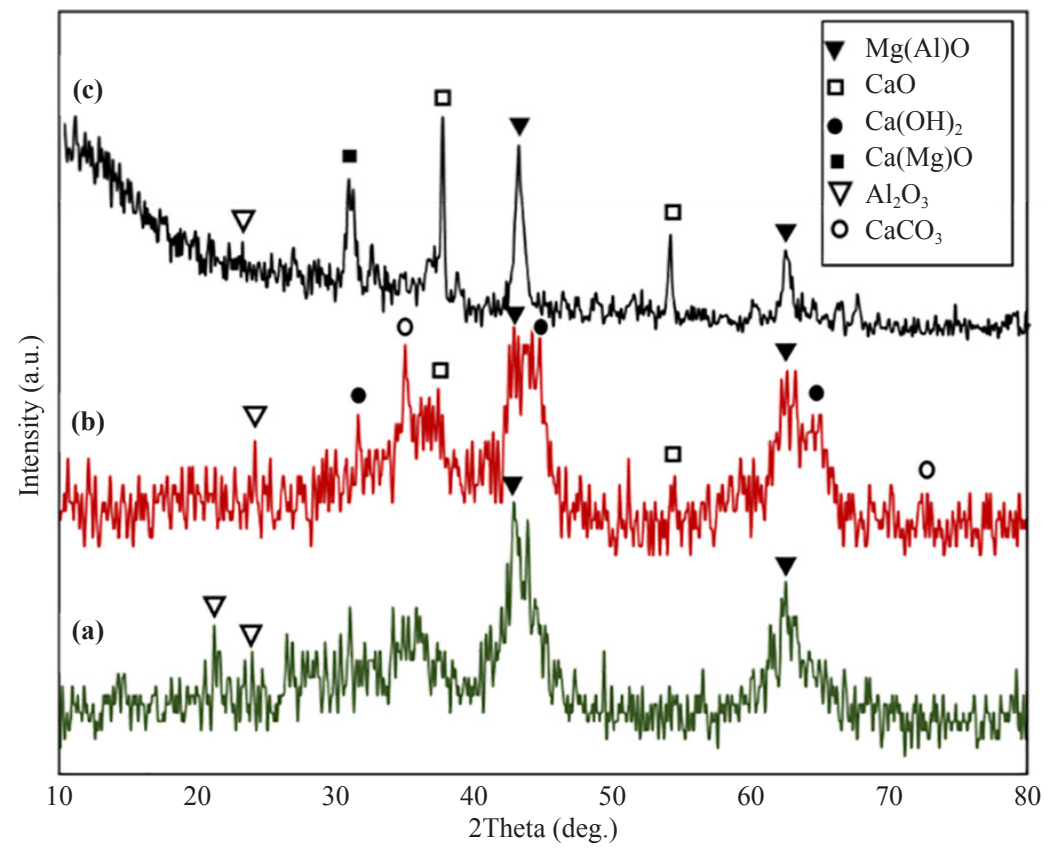

Figure 2. XRD spectra of $\operatorname{MgAl}(\mathrm{O})(\mathrm{a}), \mathrm{Ca}-\mathrm{MgAl}(\mathrm{b})$ and $\mathrm{CaMgAl}(\mathrm{O})(\mathrm{c})$ 
The XRD spectra of $\mathrm{MgAl}(\mathrm{O}), \mathrm{Ca}-\mathrm{MgAl}$ and $\mathrm{CaMgAl}(\mathrm{O})$ are displayed in Figure 2 (a), (b) and (c), respectively. In all patterns, the peak at $2 \theta=45^{\circ}$ corresponded to the periclase structure of the $\mathrm{MgO}$ phase overlapped with tetrahedral alumina [JCPDS 75-1525]. Diffraction peaks at about $63^{\circ}$ indicate the presence of a hexagonal structure of $\mathrm{Mg} / \mathrm{Al}$ mixed oxide. In the mentioned structure $\mathrm{Al}^{3+}$ cations are dispersed throughout the $\mathrm{MgO}$ lattice [34]. This structure seems to be generated by the calcination of $\mathrm{MgAl}$ hydrotalcite. Compared with $\mathrm{MgAl}(\mathrm{O})$, the newly emerged peaks for $\mathrm{Ca}-$ $\mathrm{MgAl}$ and $\mathrm{CaMgAl}(\mathrm{O})$. The $\mathrm{CaO}$ diffractions [JCPDS 82-1691] are clearly visualized for $\mathrm{Ca}-\mathrm{MgAl}$ and $\mathrm{CaMgAl}(\mathrm{O})$. $\mathrm{Ca}(\mathrm{OH})_{2}$ (JCPDS 084-1263) and $\mathrm{CaCO}_{3}$ (JCPDS 033-0268) were also observed for the Ca-MgAl and $\mathrm{CaMgAl}(\mathrm{O})$ catalysts. This is due to the hydration and carbonation of basic $\mathrm{CaO}$ in contact with air [37-38].

The surface morphological features and elemental composition of $\operatorname{MgAl}(\mathrm{O}), \mathrm{Ca}-\mathrm{MgAl}$ and $\mathrm{CaMgAl}(\mathrm{O})$ were characterized by SEM and EDX analysis, respectively.

Figure 3 shows SEM images of the $\mathrm{MgAl}(\mathrm{O}), \mathrm{CaMgAl}(\mathrm{O})$ and $\mathrm{Ca}-\mathrm{MgAl}$. Based on the SEM micrograph, it shows that the as-synthesized catalysts exhibit plate-like and irregular surface. The plate-like structure provides a high surface area for catalytic applications. Upon calcination, the samples sintering occurred. As shown in Figure 3, MgAl(O), $\mathrm{CaMgAl}(\mathrm{O})$ and $\mathrm{Ca}-\mathrm{MgAl}$ present a layer structure. Figure 3 (d) displays a magnified picture of Ca-MgAl where a layer structure and platelets could be observed.
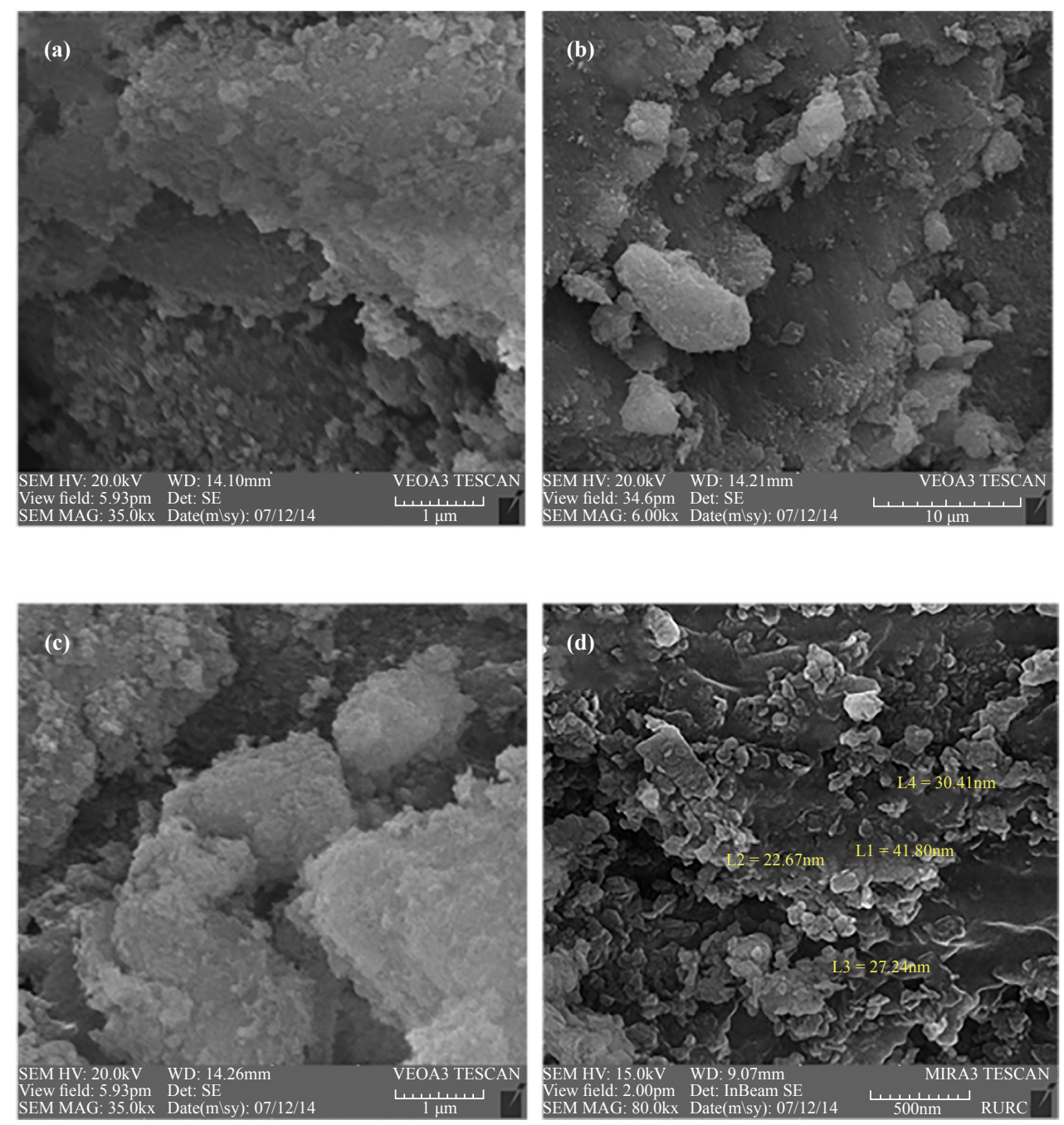

Figure 3. SEM micrographs of $\mathrm{MgAl}(\mathrm{O})$ (a), $\mathrm{Ca}-\mathrm{MgAl}(\mathrm{b})$ and $\mathrm{CaMgAl}(\mathrm{O})$ (c), and FE-SEM image of $\mathrm{Ca}-\mathrm{MgAl}(\mathrm{d})$ 

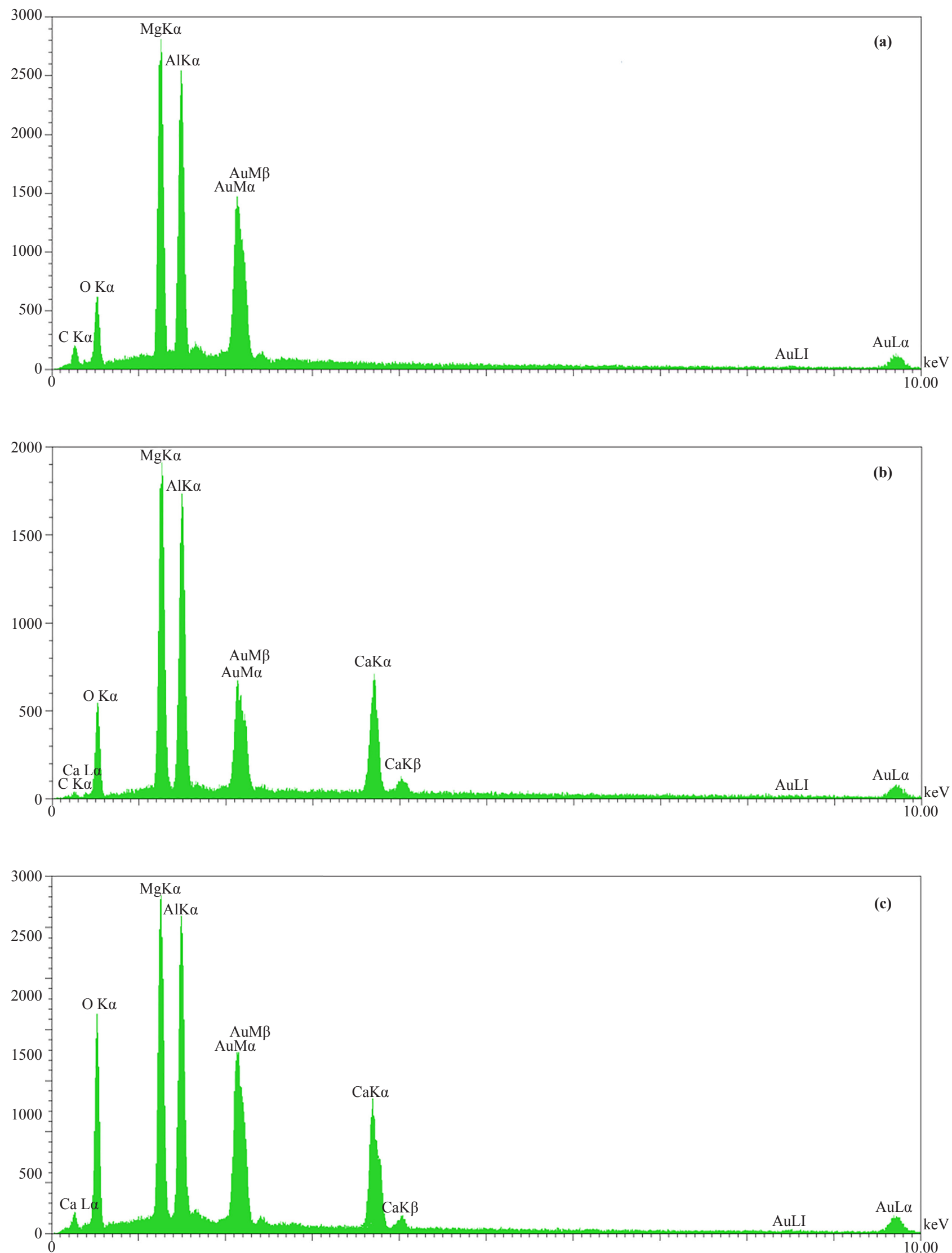

Figure 4. EDX spectra of $\mathrm{MgAl}(\mathrm{O})(\mathrm{a}), \mathrm{Ca}-\mathrm{MgAl}(\mathrm{b})$ and $\mathrm{CaMgAl}(\mathrm{O})$ (c) 
The elements constructing the $\mathrm{MgAl}(\mathrm{O}), \mathrm{Ca}-\mathrm{MgAl}$ and $\mathrm{CaMgAl}(\mathrm{O})$ were analyzed by the EDX and their results are presented in Figure 4. The peaks appeared in the regions of 1.20 and $1.50 \mathrm{keV}$ are related to the binding energies of $\mathrm{Mg}$ and $\mathrm{Al}$, respectively. Moreover, the peaks appeared in the regions of 3.70 and $4.05 \mathrm{keV}$ are related to the binding energies of $\mathrm{Ca}$. The presence of gold peak $\mathrm{Au}$ ) in the spectra is due to the gold coating process of the sample to enhance the electric conduction and to improve the quality of the images [39]. The EDX data of the nanocatalysts is useful to know the amount of surface Ca content of the catalysts and also is important to determine leaching values of surface contents of them after reaction [31, 40]. The leaching of the Ca species reduces the reusability of the catalyst and increases processing cost [41]. The initial Ca content of both catalysts is shown in Table 1. As is clear from these data, the Ca content of the co-precipitated catalyst is higher than impregnated one. It can be seen from Figure 4(b) and (c) that the intensity of the characteristic Ca peaks increases with the increase of increase content [42-43]. This result is acceptable considering and comparing the initial Ca salt for the synthesis of each mixed oxide.

XRF spectroscopy was performed to obtain the elemental composition of the materials. The elemental composition of the $\mathrm{Ca}-\mathrm{MgAl}$ and $\mathrm{CaMgAl}(\mathrm{O})$ are given in Table 2. The main component of prepared catalysts is cations such as $\mathrm{Mg}$, $\mathrm{Al}, \mathrm{Ca}$, and $\mathrm{Na}$.

Table 2. Elemental composition of synthesized catalysts

\begin{tabular}{ccccc}
\hline Catalysts & $\mathrm{Mg}(\%)$ & $\mathrm{Al}(\%)$ & $\mathrm{Ca}(\%)$ & $\mathrm{Na}(\%)$ \\
\hline Ca-MgAl & 38.20 & 36.99 & 16.85 & 7.96 \\
CaMgAl(O) & 29.30 & 26.24 & 23.32 & 8.13 \\
\hline
\end{tabular}

FT-IR spectrum is an important tool for detecting the characteristic functional groups on the surface of catalysts. Figure 5 showed the FT-IR spectra of $\mathrm{Ca}-\mathrm{MgAl}$ and $\mathrm{CaMgAl}(\mathrm{O})$. The broad peak in the range of $3000-3750 \mathrm{~cm}^{-1}$ belongs to the $\mathrm{OH}$ stretching vibration peak of crystallization water and containing hydrogen bonds [44-45]. The strong absorption peak at $1625 \mathrm{~cm}^{-1}$ belongs to the $\mathrm{OH}$ bending vibration peak of water. The band at $1510 \mathrm{~cm}^{-1} \mathrm{can}$ be ascribed to the O-C-O stretching vibrations of adsorbed carbonate anions on the surface basic sites of the catalysts [46-47]. The other bands observed in the range $500-850 \mathrm{~cm}^{-1}$ are mainly due to M-O, M-O-M, and O-M-O lattice vibrations [48-50]. These observations confirmed the formation of catalysts.

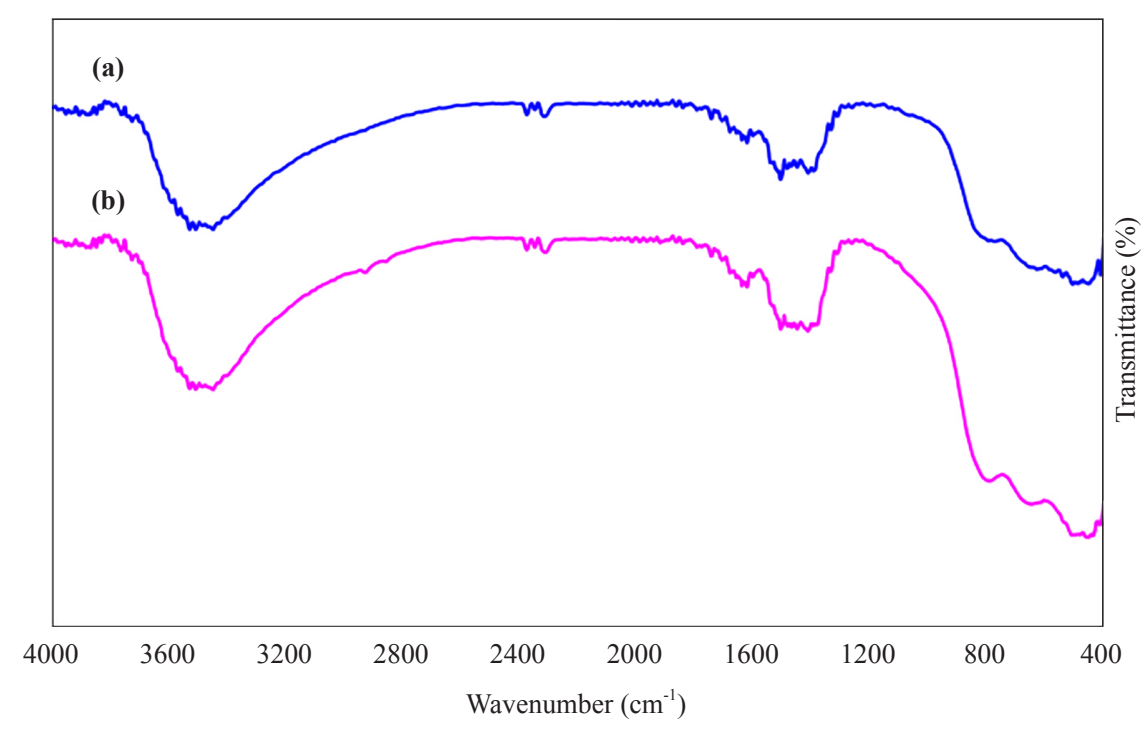

Figure 5. FT-IR spectra of the $\mathrm{Ca}-\mathrm{MgAl}$ (a) and $\mathrm{CaMgAl}(\mathrm{O})$ (b) 
The $\mathrm{N}_{2}$ adsorption-desorption isotherm and the PSD (inset) of $\mathrm{CaMgAl}(\mathrm{O})$ and Ca-MgAl are shown in Figure 6 and Figure 7, respectively. Also, Table 1 displays the textural parameters of these materials. The obtained isotherms could be classified as the type-IV isotherm and the H3 hysteresis loop according to the IUPAC classification [51-52]. The IV type is characterized by the hysteresis loop and the desirable adsorption proceeds at the high-pressure $\mathrm{P} / \mathrm{P}_{0}$. The $\mathrm{N}_{2}$ isotherm of the $\mathrm{Ca}-\mathrm{MgAl}$ showed a similar shape as the $\mathrm{CaMgAl}(\mathrm{O})$. Therefore, there is a slight change in the structure of the $\mathrm{Ca}$ impregnation sample. The BET surface area of $\mathrm{Ca}-\mathrm{MgAl}$ was four times higher than the $\mathrm{CaMgAl}(\mathrm{O})$. The pore diameter of impregnated $\mathrm{Ca}-\mathrm{MgAl}$ catalyst is a little lower than the $\mathrm{CaMgAl}(\mathrm{O})$ sample. The PSD plot represented that the majority of the pores in $\mathrm{CaMgAl}(\mathrm{O})$ and $\mathrm{Ca}-\mathrm{MgAl}$ have a diameter of approximately 22.25 and $20.04 \mathrm{~nm}$, respectively.

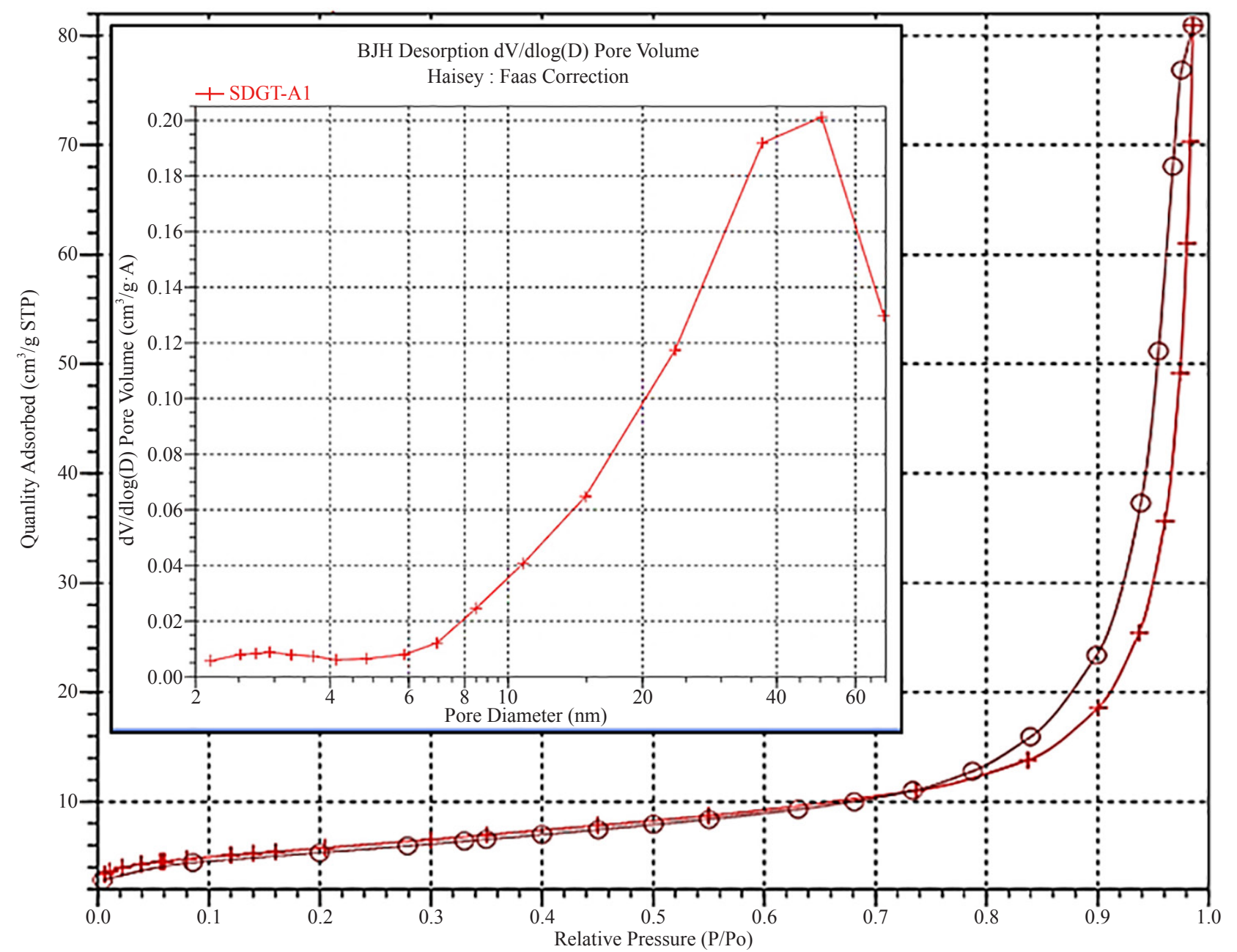

Figure 6. $\mathrm{N}_{2}$ isotherm and $\mathrm{PSD}$ (inside) of $\mathrm{CaMgAl}(\mathrm{O})$

The FAME yield of prepared mixed metal oxides was defined as following equation:

$$
\text { Yield } \%=\frac{\sum(\mathrm{A})-\mathrm{A}_{\text {is }}}{\mathrm{A}_{\text {is }}} \times \frac{\mathrm{W}_{\text {is }}}{\mathrm{m}} \times 100
$$

Where yield\% represents FAME percentage from GC analysis, $\mathrm{A}$ and $\mathrm{A}_{\text {is }}$ represent the total surface area of the peaks of the chromatograph and internal standard, respectively; $\mathrm{W}_{\mathrm{is}}$ and $\mathrm{m}$ represent the mass of the internal standard and sample which was injected into the system, respectively. 


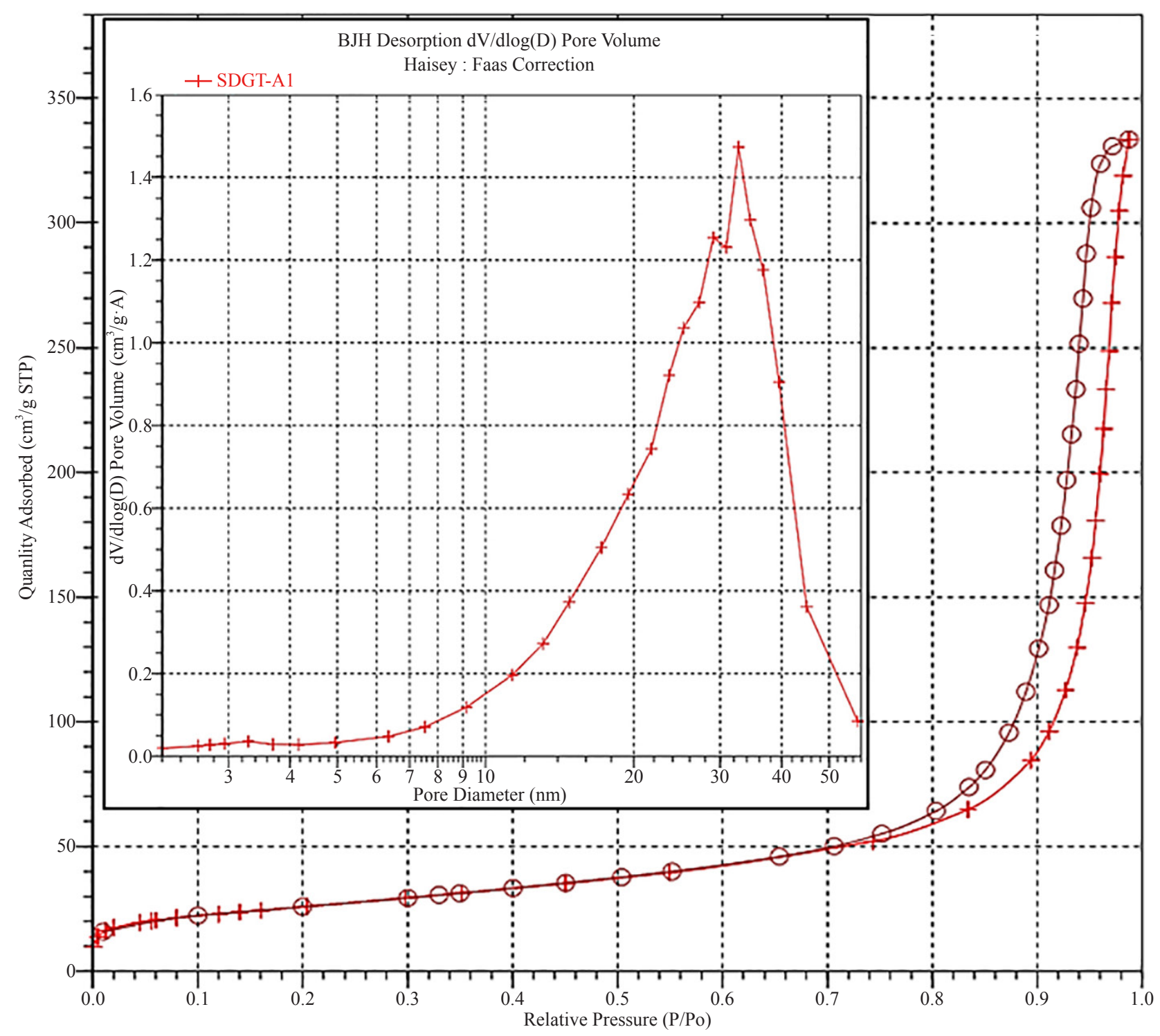

Figure 7. $\mathrm{N}_{2}$ isotherm and PSD (inside) of Ca-MgAl

The GC chromatograms for biodiesel produced using $\mathrm{Ca}-\mathrm{MgAl}$ and $\mathrm{CaMgAl}(\mathrm{O})$ are shown in Figure 8 . The appeared peaks represent different types of the FAME contents in the mixture each of which is a product of their assigned fatty acids. For instance, the intense peak at about $1.8 \mathrm{~min}$ represents the presence of butyrate in the final mixture which is the product of transesterification of butyric acid (C4:0). The one at $18.25 \mathrm{~min}$ represents the presence of methyl octadecenoate (C18:0) which was produced through transesterification of methyl octadecenoic acid.

The reaction mechanism for the preparation of biodiesel by transesterification of oil in the presence of metal oxides is reported in our previous work [35]. Based on the reports of Chouhan et. al [41], Figure 9 is illustrating the suggested mechanism in which the metal oxide forms a bond with alcohol, creating nucleophilic oxygen on the alcohol. This oxygen then attacks the carbonyl carbon on the triglyceride which prompts the usual transesterification reaction mechanism. 

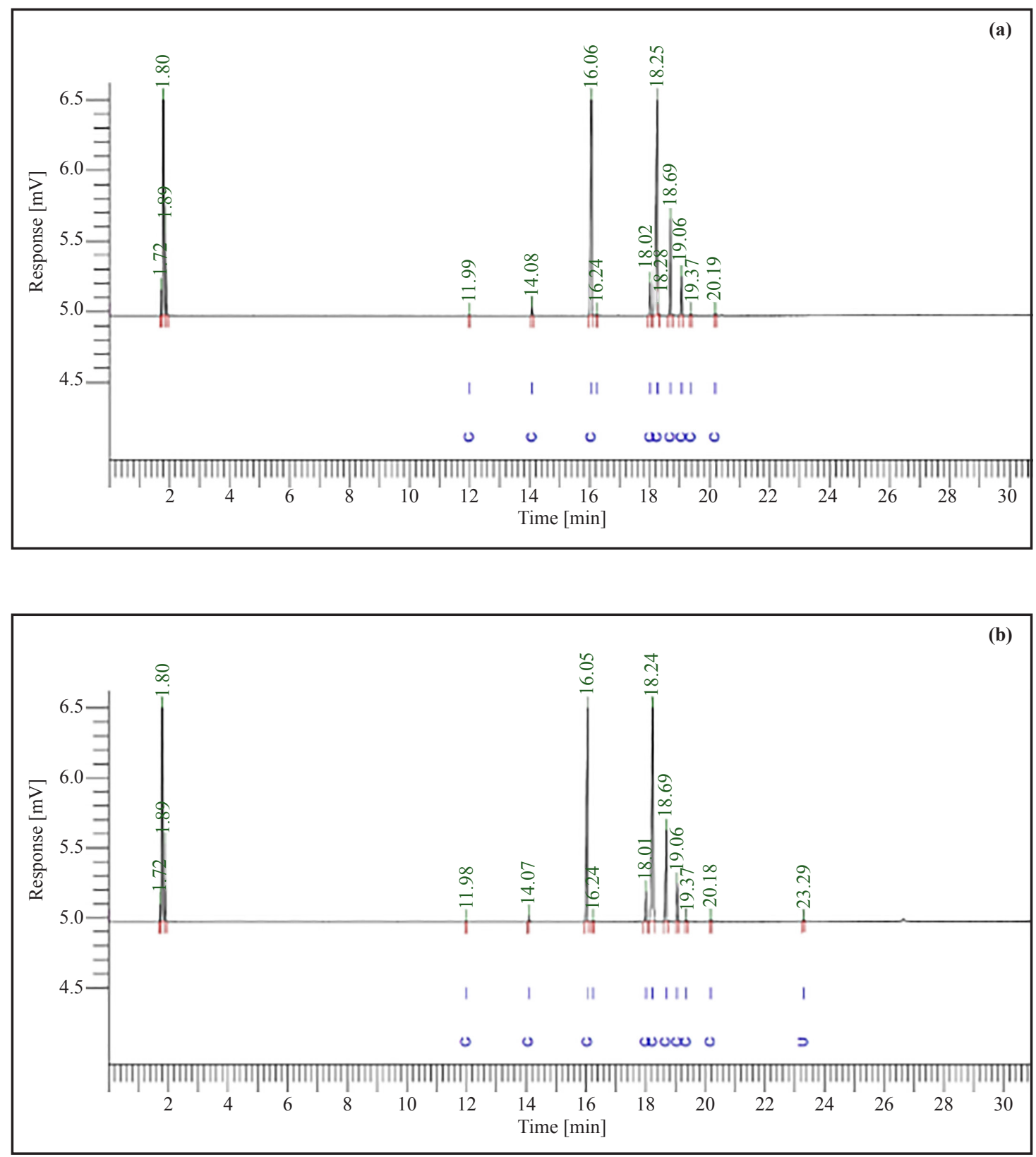

Figure 8. GC chromatogram for biodiesel produced using $\mathrm{CaMgAl}(\mathrm{O})$ (a) and $\mathrm{Ca}-\mathrm{MgAl}(\mathrm{b})$ catalysts

Using the EDX analysis, it is possible to achieve leaching amounts of catalyst components after the reaction and these data can be compared with the initial EDX data from the catalysts. The data obtained from EDX analysis are collected in Table 3 .

Table 3. FAME yield of catalysts and leaching values of the catalyst components

\begin{tabular}{ccccc}
\hline Catalyst type & Ca leaching (wt \%) & Mg leaching (wt \%) & Al leaching (wt \%) & FAME yield (\%) \\
\hline CaMgAl$(\mathrm{O})$ & $-45.88 \%$ & $-2.11 \%$ & $-2.07 \%$ & 90.25 \\
$\mathrm{Ca}-\mathrm{MgAl}$ & $-8.01 \%$ & $-3.16 \%$ & $-1.15 \%$ & 89.17 \\
\hline
\end{tabular}




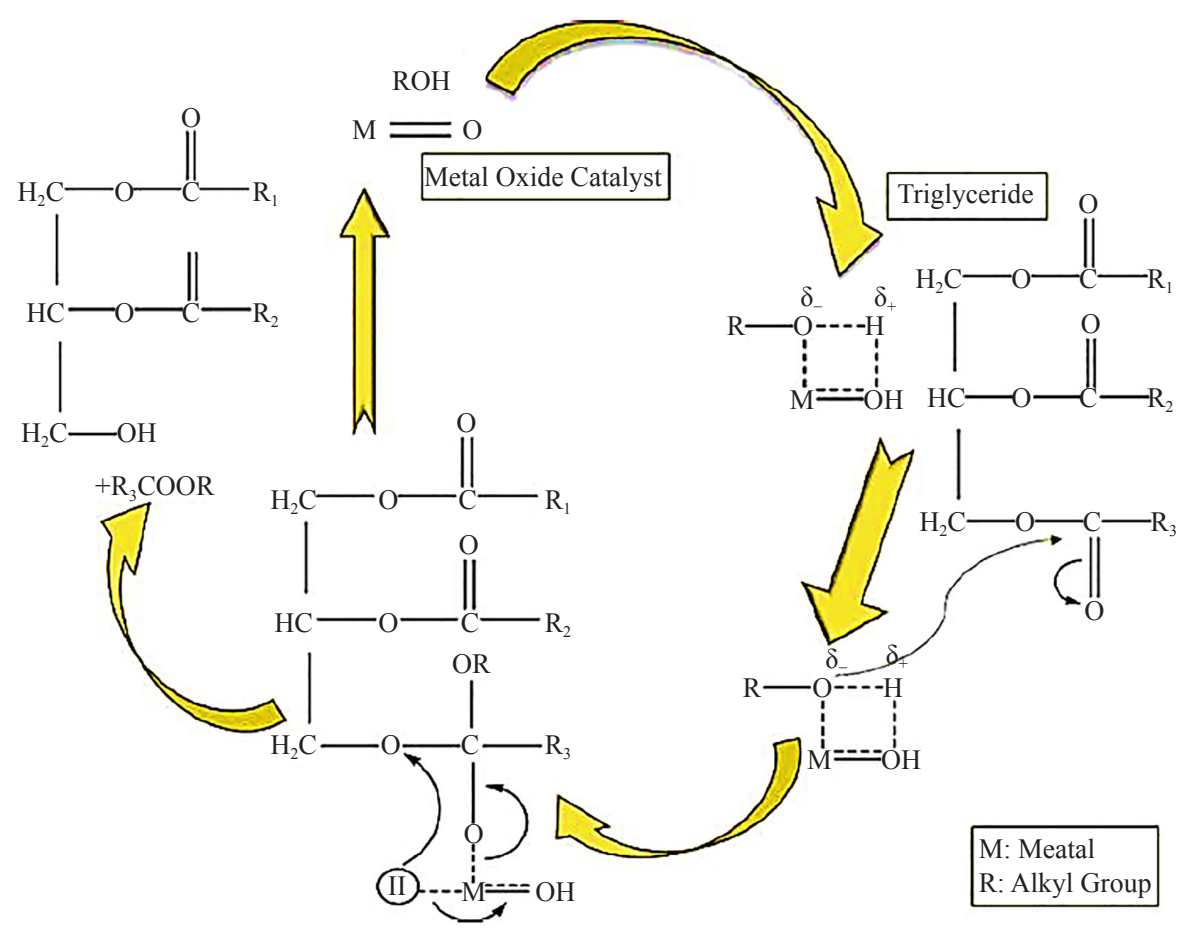

Figure 9. Schematic illustration of a mechanism for basic metal oxide catalyzed transesterification [41]

As shown in Table 3, the leaching of Ca that was considered the main part of catalysts is over five times lower for impregnated $\mathrm{Ca}-\mathrm{MgAl}$ compared with co-precipitated $\mathrm{CaMgAl}(\mathrm{O}) . \mathrm{CaO}$ is known as an appropriate catalyst or catalytic substrate for biodiesel production through transesterification [53-54]. In our developed catalyst, $\mathrm{CaO}$ is more active than other components for the transesterification procedure.

This finding indicated that the impregnation method gave a high mechanical strength catalyst, so some reports indicate that the impregnation technique for developing multi-component catalysts showed better performance than coprecipitation [55]. In this technique, nanoparticles of the active catalytic component were well-dispersed throughout the substrate which could provide appropriate activity and decrease the leaching effect.

$\mathrm{Mg}$ and $\mathrm{Al}$ leaching values of both catalysts were approximately close to each other. Although impregnated catalyst ( $\mathrm{Ca}-\mathrm{MgAl})$ contained lower initial $\mathrm{Ca}$ and basic strength as compared with $\mathrm{CaMgAl}(\mathrm{O})$ (as noted before), the FAME yields of them were almost the same. These results might be due to the structure of the $\mathrm{Ca}-\mathrm{MgAl}$ that contained $\mathrm{MgAl}$ platelet with $\mathrm{CaO}$ nanoparticles. The presence of dispersed $\mathrm{CaO}$ nanoparticles on the $\mathrm{Ca}-\mathrm{MgAl}$ catalyst provides high active surface area and enhances catalytic performance for various applications [55]. Such a high surface area structure provided a large quantity of active sites and showed high performance even with a small number of active components. Compared to the co-precipitation method, the impregnation method is relatively simple and suitable for synthesizing nanoporous catalysts on large scale. Using a smaller amount of raw materials, this method produces catalysts that have high performance with high mechanical strength.

\section{Conclusion}

In this research, biodiesel was produced with transesterification reactions employing two types of mixed metal oxide catalysts produced through two different methods using $\mathrm{Ca}, \mathrm{Mg}$ and $\mathrm{Al}$ salts. The synthesized catalysts were characterized in relation to their functional groups (FTIR), crystallinity (XRD), surface area (BET), elemental composition (EDX and XRF), PSD (BJH) and morphology (SEM). Analysis of changes in chemical structure and formation of FAME was analyzed using $\mathrm{GC}$. $\mathrm{CaO}$ impregnated $\mathrm{MgAl}(\mathrm{O})$ showed a higher surface area and better 
mechanical strength than totally co-precipitated $\mathrm{CaMgAl}(\mathrm{O}) . \mathrm{Ca}-\mathrm{MgAl}$ catalyst with the lower initial value of $\mathrm{Ca}$ and basicity, in comparison with $\mathrm{CaMgAl}(\mathrm{O})$, revealed similar catalytic activity in the transesterification reaction. The high activity of $\mathrm{Ca}-\mathrm{MgAl}$ may be due to the high surface area of this type of catalyst. This is explained by the fact that the spatial structure contains both nano platelets and nano particles together. The experimental results confirmed that the impregnation method for the synthesis of calcium-based $\mathrm{MgAl}(\mathrm{O})$ nanoporous catalysts is better than the coprecipitation method. This method is simple, inexpensive and suitable for large-scale synthesis of prepared catalysts and produces high performance and superior mechanical strength catalysts.

\section{Reference}

[1] Shan R, Lu L, Shi Y, Yuan H, Shi J. Catalysts from renewable resources for biodiesel production. Energy Conversion and Management. 2018; 178: 277-289.

[2] Salehi S, Anbia M. Highly efficient $\mathrm{CO}_{2}$ capture with a metal-organic framework-derived porous carbon impregnated with polyethyleneimine. Applied Organometallic Chemistry. 2018; 32(7): e4390.

[3] Zohdi S, Anbia M, Salehi S. Improved $\mathrm{CO}_{2}$ adsorption capacity and $\mathrm{CO}_{2} / \mathrm{CH}_{4}$ and $\mathrm{CO}_{2} / \mathrm{N}_{2}$ selectivity in novel hollow silica particles by modification with multi-walled carbon nanotubes containing amine groups. Polyhedron. 2019; 166: 175-185.

[4] Adewuyi A. Challenges and prospects of renewable energy in Nigeria: A case of bioethanol and biodiesel production. Energy Reports. 2020; 6: 77-88.

[5] Singh D, Sharma D, Soni SL, Sharma S, Kumar Sharma P, Jhalani A. A review on feedstocks, production processes, and yield for different generations of biodiesel. Fuel. 2020; 262: 116553.

[6] Ferrero GO, Sánchez Faba EM, Rickert AA, Eimer GA. Alternatives to rethink tomorrow: Biodiesel production from residual and non-edible oils using biocatalyst technology. Renewable Energy. 2020; 150: 128-135.

[7] Suresh M, Jawahar CP, Richard A. A review on biodiesel production, combustion, performance, and emission characteristics of non-edible oils in variable compression ratio diesel engine using biodiesel and its blends. Renewable and Sustainable Energy Reviews. 2018; 92: 38-49.

[8] Talebian-Kiakalaieh A, Amin NAS, Mazaheri H. A review on novel processes of biodiesel production from waste cooking oil. Applied Energy. 2013; 104: 683-710.

[9] Petchsoongsakul N, Ngaosuwan K, Kiatkittipong W, Wongsawaeng D, Assabumrungrat S. Different water removal methods for facilitating biodiesel production from low-cost waste cooking oil containing high water content in hybridized reactive distillation. Renewable Energy. 2020; 162: 1906-1918.

[10] Bemani A, Xiong Q, Baghban A, Habibzadeh S, Mohammadi AH, Doranehgard MH. Modeling of cetane number of biodiesel from fatty acid methyl ester (FAME) information using GA-, PSO-, and HGAPSO-LSSVM models. Renewable Energy. 2020; 150: 924-934.

[11] Roosta A. New group interaction parameters of the UNIFAC model for the solubility of water in fatty acid methyl esters and biodiesel. Fuel. 2018; 220: 339-344.

[12] Nejati S, Mirbagheri SA, Warsinger DM, Fazeli M. Biofouling in seawater reverse osmosis (SWRO): Impact of module geometry and mitigation with ultrafiltration. Journal of Water Process Engineering. 2019; $29: 100782$.

[13] Atadashi I, Aroua M, Aziz AA, Sulaiman N. The effects of catalysts in biodiesel production: A review. Journal of Industrial and Engineering Chemistry. 2013; 19(1): 14-26.

[14] Shimada GB, Cestari A. Synthesis of heterogeneous catalysts by the hydrolytic Sol-Gel method for the biodiesel production. Renewable Energy. 2020; 156: 389-394.

[15] Nejati S, Mirbagheri SA, Waimin J, Grubb ME, Peana S, Warsinger DM, et al. Laser functionalization of carbon membranes for effective immobilization of antimicrobial silver nanoparticles. Journal of Environmental Chemical Engineering. 2020; 8(5): 104109.

[16] Nath B, Das B, Kalita P, Basumatary S. Waste to value addition: Utilization of waste Brassica nigra plant derived novel green heterogeneous base catalyst for effective synthesis of biodiesel. Journal of Cleaner Production. 2019; 239: 118112.

[17] Narasimhan M, Chandrasekaran M, Govindasamy S, Aravamudhan A. Heterogeneous nanocatalysts for sustainable biodiesel production: A review. Journal of Environmental Chemical Engineering. 2021; 9(1): 104876.

[18] Sedaghat S, Ahadian MM, Jafarian M, Hatamie S. Model fuel deep-desulfurization using modified 3D graphenic adsorbents: Isotherm, kinetic and thermodynamic study. Industrial \& Engineering Chemistry Research. 2019; 58(24): 10341-10351. 
[19] Mirbagheri SA, Nejati S, Moshirvaziri S. Numerical simulation of dissolved oxygen, algal biomass, nitrate, organic nitrogen, ammonia, and dissolved phosphorus in waste stabilization ponds. Desalination and Water Treatment. 2018; 135: 188-197.

[20] Borges ME, Díaz L. Recent developments on heterogeneous catalysts for biodiesel production by oil esterification and transesterification reactions: A review. Renewable and Sustainable Energy Reviews. 2012; 16(5): $2839-2849$.

[21] Hariprasath P, Vijayakumar V, Selvamani ST, Vigneshwar M, Palanikumar K. Some Studies on Waste Animal Tallow Biodiesel Produced by Modified Transesterification Method Using Heterogeneous Catalyst. Materials Today: Proceedings. 2019; 16: 1271-1278.

[22] Semwal S, Arora AK, Badoni RP, Tuli DK. Biodiesel production using heterogeneous catalysts. Bioresource Technology. 2011; 102(3): 2151-2161.

[23] Qu T, Niu S, Gong Z, Han K, Wang Y, Lu C. Wollastonite decorated with calcium oxide as heterogeneous transesterification catalyst for biodiesel production: Optimized by response surface methodology. Renewable Energy. 2020; 159: 873-884.

[24] Al-Saadi A, Mathan B, He Y. Biodiesel production via simultaneous transesterification and esterification reactions over $\mathrm{SrO}-\mathrm{ZnO} / \mathrm{Al}_{2} \mathrm{O}_{3}$ as a bifunctional catalyst using high acidic waste cooking oil. Chemical Engineering Research and Design. 2020; 162: 238-248.

[25] Sedaghat S, Piepenburg CR, Zareei A, Qi Z, Peana S, Wang H, et al. Laser-Induced Mesoporous Nickel Oxide as Highly Sensitive Nonenzymatic Glucose Sensor. ACS Applied Nano Materials. 2020; 3(6): 5260-5270.

[26] Acosta PI, Campedelli RR, Correa EL, Bazani HAG, Nishida EN, Souza BS, et al. Efficient production of biodiesel by using a highly active calcium oxide prepared in presence of pectin as heterogeneous catalyst. Fuel. 2020; 271: 117651.

[27] Devaraj K, Veerasamy M, Aathika S, Mani Y, Thanarasu A, Dhanasekaran A, et al. Study on effectiveness of activated calcium oxide in pilot plant biodiesel production. Journal of Cleaner Production. 2019; 225: 18-26.

[28] Waimin JF, Nejati S, Jiang H, Qiu J, Wang J, Verma MS, et al. Smart capsule for non-invasive sampling and studying of the gastrointestinal microbiome. RSC Advances. 2020; 10(28): 16313-16322.

[29] Islam A, Taufiq-Yap YH, Chu C-M, Chan E-S, Ravindra P. Studies on design of heterogeneous catalysts for biodiesel production. Process Safety and Environmental Protection. 2013; 91(1-2): 131-144.

[30] Peterson G, Scarrah W. Rapeseed oil transesterification by heterogeneous catalysis. Journal of the American Oil Chemists Society. 1984; 61(10): 1593-1597.

[31] Castro CS, Júnior LCFG, Assaf JM. The enhanced activity of Ca/MgAl mixed oxide for transesterification. Fuel Processing Technology. 2014; 125: 73-78.

[32] Albuquerque MC, Santamaría-González J, Mérida-Robles JM, Moreno-Tost R, Rodríguez-Castellón E, JiménezLópez A, et al. $\mathrm{MgM}(\mathrm{M}=\mathrm{Al}$ and $\mathrm{Ca})$ oxides as basic catalysts in transesterification processes. Applied Catalysis A: General. 2008; 347(2): 162-168.

[33] Liu Y, Lotero E, Goodwin Jr JG, Mo X. Transesterification of poultry fat with methanol using Mg-Al hydrotalcite derived catalysts. Applied Catalysis A: General. 2007; 331: 138-148.

[34] Xie W, Peng H, Chen L. Calcined Mg-Al hydrotalcites as solid base catalysts for methanolysis of soybean oil. Journal of Molecular Catalysis A: Chemical. 2006; 246(1-2): 24-32.

[35] Sedaghat-Hoor S, Anbia M. ZnO impregnated MgAl (O) catalyst with improved properties for biodiesel production: The influence of synthesis method on stability and reusability. Particulate Science and Technology. 2019; 37(7): 897-903.

[36] Fraile JM, García N, Mayoral JA, Pires E, Roldán L. The basicity of mixed oxides and the influence of alkaline metals: The case of transesterification reactions. Applied Catalysis A: General. 2010; 387(1-2): 67-74.

[37] Granados ML, Poves MZ, Alonso DM, Mariscal R, Galisteo FC, Moreno-Tost R, et al. Biodiesel from sunflower oil by using activated calcium oxide. Applied Catalysis B: Environmental. 2007; 73(3-4): 317-326.

[38] Kouzu M, Hidaka J-s. Transesterification of vegetable oil into biodiesel catalyzed by CaO: A review. Fuel. 2012; 93: 1-12.

[39] Salehi S, Hosseinifard M. Highly efficient removal of phosphate by lanthanum modified nanochitosan-hierarchical ZSM-5 zeolite nanocomposite: characteristics and mechanism. Cellulose. 2020; 27: 4637-4664.

[40] Kumar D, Ali A. Transesterification of low-quality triglycerides over a $\mathrm{Zn} / \mathrm{CaO}$ heterogeneous catalyst: Kinetics and reusability studies. Energy \& Fuels. 2013; 27(7): 3758-3768.

[41] Chouhan AS, Sarma A. Modern heterogeneous catalysts for biodiesel production: A comprehensive review. Renewable and Sustainable Energy Reviews. 2011; 15(9): 4378-4399.

[42] Titus D, James Jebaseelan Samuel E, Roopan SM. Chapter 12-Nanoparticle characterization techniques. In: Shukla AK, Iravani S. (eds.) Green Synthesis, Characterization and Applications of Nanoparticles. Elsevier; 2019. p.303- 
319.

[43] Newbury DE. Mistakes encountered during automatic peak identification of minor and trace constituents in electron-excited energy dispersive X-ray microanalysis. Scanning: The Journal of Scanning Microscopies. 2009; 31(3): 91-101.

[44] Salehi S, Hosseinifard M. Evaluation of $\mathrm{CO}_{2}$ and $\mathrm{CH}_{4}$ adsorption using a novel amine modified MIL-101-derived nanoporous carbon/polysaccharides nanocomposites: Isotherms and thermodynamics. Chemical Engineering Journal. 2021; 410: 128315.

[45] Salehi S, Hosseinifard M. Optimized removal of phosphate and nitrate from aqueous media using zirconium functionalized nanochitosan-graphene oxide composite. Cellulose. 2020; 27: 4637-4664.

[46] Palmer SJ, Frost RL, Ayoko G, Nguyen T. Synthesis and Raman spectroscopic characterisation of hydrotalcite with $\mathrm{CO}_{3}{ }^{2-}$ and $\left(\mathrm{MoO}_{4}\right)^{2-}$ anions in the interlayer. Journal of Raman Spectroscopy: An International Journal for Original Work in all Aspects of Raman Spectroscopy, Including Higher Order Processes, and also Brillouin and Rayleigh Scattering. 2008; 39(3): 395-401.

[47] Ramos-Ramírez E, Ortega NLG, Soto CAC, Gutiérrez MTO. Adsorption isotherm studies of chromium (VI) from aqueous solutions using sol-gel hydrotalcite-like compounds. Journal of hazardous materials. 2009; 172(2-3): 1527-1531.

[48] Shamsayei M, Yamini Y, Asiabi H, Safari M. On-line packed magnetic in-tube solid phase microextraction of acidic drugs such as naproxen and indomethacin by using $\mathrm{Fe}_{3} \mathrm{O}_{4} @ \mathrm{SiO}_{2} @$ layered double hydroxide nanoparticles with high anion exchange capacity. Microchimica Acta. 2018; 185(3): 1-10.

[49] Palmer SJ, Frost RL, Nguyen T. Hydrotalcites and their role in coordination of anions in Bayer liquors: anion binding in layered double hydroxides. Coordination Chemistry Reviews. 2009; 253(1-2): 250-267.

[50] Xu ZP, Jin Y, Liu S, Hao ZP, Lu GQM. Surface charging of layered double hydroxides during dynamic interactions of anions at the interfaces. Journal of Colloid and Interface Science. 2008; 326(2): 522-529.

[51] Eshraghi F, Anbia M, Salehi S. Dative post synthetic methods on SBUs of MWCNT@MOFs hybrid composite and its effect on $\mathrm{CO}_{2}$ uptake properties. Journal of Environmental Chemical Engineering. 2017; 5(5): 4516-4523.

[52] Salehi S, Mandegarzad S, Anbia M. Preparation and characterization of metal organic framework-derived nanoporous carbons for highly efficient removal of vanadium from aqueous solution. Journal of Alloys and Compounds. 2020; 812: 152051.

[53] Boey P-L, Maniam GP, Abd Hamid S. Performance of calcium oxide as a heterogeneous catalyst in biodiesel production: A review. Chemical Engineering Journal. 2011; 168(1): 15-22.

[54] Anbia M, Masoomi S, Sedaghat S, Sepehrian M. Potassium halides-impregnated eggshell as a heterogeneous nanocatalysts for biodiesel production. Journal of Environmental Treatment Techniques. 2019; 7(1): 103-108.

[55] Allaedini G, Tasirin SM, Aminayi P. Synthesis of Fe-Ni-Ce trimetallic catalyst nanoparticles via impregnation and co-precipitation and their application to dye degradation. Chemical Papers. 2016; 70(2): 231-242. 